\title{
HUBUNGAN DUKUNGAN SOSIAL DAN MEKANISME KOPING DENGAN TINGKAT STRESS SANTRI PONDOK PESANTREN NURUL JADID PAITON PROBOLINGGO
}

\author{
Mohammad Irwansyah*, Sri Astutik Andayani, Husnul Khotimah \\ Fakultas Kesehatan Universitas Nurul Jadid Paiton Probolinggo, \\ *e-mail: mohammadirwansyah27@gmail.com
}

\begin{abstract}
Keywords:

Stres dapat dialami oleh siapa saja dan berdampak negatif jika

Dukungan Sosial,

Mekanisme

terakumulasi dalam kehidupan seseorang tanpa solusi yang tepat. Stres

Koping, Stres

sering terjadi pada santri dengan adanya kegiatan yang sangat padat.

Tujuan dari penelitian ini untuk mengetahui hubungan dukungan sosial dan mekanisme koping dengan tingkat stres santri di Pondok Pesantren Nurul Jadid Paiton. Desain penelitian yang digunakan dalam penelitian ini adalah Cros-Secsional. Populasi pada penelitian ini adalah semua santri di Wilayah Sunan Muria (L) Pondok Pesantren Nurul Jadid dengan total responden 80 santri. Tekhnik sampel yang digunakan yaitu Total Sampling dengan uji Chi Square. Hasil penelitian dengan menggunakan uji statistik Chi Square menunjukkan nilai signifikan dukungan sosial dengan tingkat stres $\rho$ value 0,018<0,05. sedangkan nilai signifikan mekanisme koping dengan tingkat stres $\rho$ value $0,021<0,05$, artinya terdapat hubungan yang signifikan antara dukungan sosial dan mekanisme koping dengan tingkat stres santri di Pondok Pesantren Nurul Jadid Paiton. Artinya semakin tinggi dukungan sosial maka semakin mengurang tingat stress yang dialami santri dan semakin rendah dukungan sosial maka semakin meningkat tingkat stress yang dialami santri. Artinya semakin santri menggunakan mekanisme koping adaptif untuk mengatasi stressnya maka semakin berkurang tingkat stressnya yang dalaminya dan apabila santri menggunakan koping maladaptif untuk mengatasi stressnya maka semaking meningkat tingkat stress yang dialaminya.
\end{abstract}

\section{PENDAHULUAN}

Masa remaja merupakan masa peralihan dari anak - anak menuju masa dewasa, pada proses pencarian jati diri banyak menimbulkan konflik baik bagi diri maupun orang lain. Dari remaja yang mengalami permasalahan yang dapat disebabkan dari faktor internal dan faktor eksternal (Yani \& Retnowuni, 2019). Remaja sering berfikir mengenai hal - hal yang mungkin terjadi seperti halnya, mereka memikirkan karakteristik ideal diri mereka sendiri, orang lain, dan dunia atau secara emosi, perkembangan emosi remaja masih sangat labil (Astuti, 2015). Ada 3 tahap perkembangan remaja, yaitu remaja awal, remaja madya, remaja akhir. Remaja awal memiliki rentang usia antara 11-13 tahun, remaja madya memiliki rentang usia antara 14-16 tahun, remaja akhir memiliki rentang usia antara 17-20 tahun (Sarwono, 2011). 
Pada fisiologiknya respon terhadap individu bermacam - macam tergantung pada bagaimana individu itu mempresepsikan suatu kejadian (Millasari \& Jannah, 2019). Dukungan sosial adalah bantuan atau dukungan yang diterima oleh individu dari orang-orang dalam kehidupan mereka yang berada dalam lingkungan sosial tertentu sehingga individu merasa diperhatikan, dihargai dan dicintai (Kuntjoro, 2012). Dengan dukungan sosial yang diberikan oleh orangtua, guru, dan individu yang bersangkutan dalam meningkatkan kualitas dukungan sosial untuk menghadapi dan mempersiapkan penanganan yang dapat dilakukan pada masalah yang terjadi (Hanifah, 2019). Untuk menghadapi adanya stress maka diperlukan mekanisme koping yang baik atau cara beradaptasi agar stress yang dihadapi tidak berkepanjangan dengan menggunakan coping stress baik pada problem focused coping maupun pada emotional focused coping (Hanifah, Millasari \& Jannah, 2019). Menurut Lazarus dan Folkman ada dua strategi mekanisme koping, yaitu problem focused coping dan emotional focused coping. Problem focused coping merupakan usaha mengatasi stres dengan cara mengatur atau mengubah masalah yang dihadapi dan lingkungan sekitarnya yang menyebabkan terjadinya tekanan sedangkan emotional focused coping merupakan usaha mengatasi stres dengan cara mengatur respons emosional dalam rangka menyesuaikan diri dengan dampak yang akan ditimbulkan oleh suatu kondisi atau situasi yang dianggap penuh tekanan (Lazarus \& Folkman, 1984).

Pada remaja yang berstatus santri dalam hal ini harus menghadapi kegiatan pembelajaran pondok yang terlalu padat, peraturan yang ketat, aktivitas yang banyak, hafalan yang harus dikuasai, serta banyak beban tuntutan yang harus dicapai sehingga menyebabkan stress (Livia \& Zulia, 2020). Remaja yang mengalami stress di Indonesia meningkat sebanyak $14 \%$ terutama yang berusia kurang lebih 15 tahun (Riskesde, 2018). Bahkan remaja yang memiliki tekanan pada dirinya akan mempengaruhi bagaimana cara remaja dalam melakukan proses adaptasi terhadap masalah yang terjadi. Remaja santri yang memiliki tekanan dalam dirinya tidak dapat menyesuaikan diri dengan baik akan melakukan tindakan yang tiak wajar seperti malas belajar, tidak mengikuti aturanaturan yang ada, kabur-kaburan dari pondok pesantren, dan melakukan hal negatif lainnya (Livia \& Zulia, 2020). Menurut Hans Selye, Stres adalah respons manusia yang bersifat nonspesifik terhadap setiap tuntutan kebutuhan yang ada dalam dirinya (Selye, 1970).

Hasil peneliti Livia bahwa tingkat stress remaja di Pondok Pesantren An-Nuqthah mayoritas dengna tingkat stress berat sebanyak 54 responden $(60,7 \%)$. Tingkat stress sedang dan stress berat yang dialami oleh remaja bisa disebabkan oleh kegiatan pembelajaran pondok yang terlalu padat, peraturan yang ketat, aktivitas yang banyak, hafalan yang harus dikuasai, serta banyak beban tuntutan yang harus dicapai (Livia \& Zulia, 2020).

Hasil penelitian Astuti dengan judul "Hubungan Antara Dukungan Sosial Orang Tua dengan Strategi Coping Berfokus Masalah pada Siswa SMK Negeri 3 Yogyakarta" menunjukkan bahwa siswa kelas XII memiliki tingkat dukungan sosial orang tua pada kategori sedang sebanyak 158 siswa $(69,6 \%)$ dan tingkat strategi coping berfokus masalah pada kategori sedang sebanyak 176 siswa $(77,5 \%)$. Diketahui bahwa dukungan sosial orang tua memberikan kontribusi pada strategi coping berfokus masalah sebesar $37,8 \%$, sedangkan $62,2 \%$ dipengaruhi oleh faktor faktor lain (Astuti, 2015).

Berdasarkan fenomena diatas, peneliti tertarik untuk melakukan penelitian "Hubungan Dukungan Sosial dan Mekanisme Koping dengan Tingkat Stres Santri di Pondok Pesantren Nurul Jadid Paiton Probolinggo". 


\section{METODE}

Penelitian ini merupakan penelitian kuantitatif korelasional menggunakan pendekanan Cross Sectional dengan populasi semua santri di Wilayah Sunan Muria (L) Pondok Pesantren Nurul Jadid dengan sebanyak 80 responden. Sampel diambil dengan menggunakan metode total sampling dengan jumlah 80 Santri. Instrumen dalam penelitian ini menggunakan kuesioner. Analisis data statistic dengan analisis univariat digunakan untuk menjabarkan secara deskriptif dukungan sosial, mekanisme koping, dan tingkat stress santri. Analisis bivariat untuk data ordinal dengan menggunakan Chi-Square dengan tingkat signifikan $(\alpha)=0,05$. Jika nilai $\rho<0,05$, maka $\mathrm{H} \alpha$ diterima. Sebliknya, jika nilai $\rho>$ 0,05 maka H0 ditolak.

\section{HASIL}

Hasil dalam penelitian ini meliputi hasil analisis univariat yang terdiri dukungan sosial, indikator dukungan sosial, mekanisme koping, indikator mekanisme koping, dan tingkat stress santri. Hasil analisis bivariat juga dijabarkan.

Tabel 1

Distribusi Frekuensi Dukungan Sosial Santri

\begin{tabular}{lcc}
\hline Dukungan Sosial & Frekuensi & Persentase \\
\hline Rendah & 26 & 32,5 \\
\hline Sedang & 8 & 10,0 \\
\hline Tinggi & 46 & 57,5 \\
\hline Jumlah & 80 & 100 \\
\hline Sumber: Data Primer Lembar Kuesioner Penelitian 2020
\end{tabular}

Berdasarkan tabel 1 diatas menunjukkan bahwa presentase terbesar responden pada dukungan sosial dalam kategori sedang yaitu 8 orang $(10,0 \%)$, sedangkan dukungan sosial pada kategori rendah yaitu dengan jumlah 26 orang (32,5\%), dan dengan dukungan sosial berkategori tinggi yaitu dengan jumlah 46 orang $(57,5 \%)$.
Tabel 2

Distribusi Frekuensi Indikator Dukungan Sosial Santri

\begin{tabular}{lcc}
\hline $\begin{array}{l}\text { Indikator Dukungan } \\
\text { Sosial }\end{array}$ & Frekuensi & Persentase \\
\hline Tangiable Support & & \\
\hline Tidak Dilakukan & 43 & 53,8 \\
\hline Dilakukan & 37 & 46,2 \\
\hline Jumlah & 80 & 100 \\
\hline Belonging Support & & \\
\hline Tidak Dilakukan & 44 & 55,0 \\
\hline Dilakukan & 36 & 45,0 \\
\hline Jumlah & 80 & 100 \\
\hline Self-esteem Support & & \\
\hline Tidak Dilakukan & 53 & 66,2 \\
\hline Dilakukan & 27 & 33,8 \\
\hline Jumlah & 80 & 100 \\
\hline Appraisal Support & & \\
\hline Tidak Dilakukan & 44 & 55,0 \\
\hline Dilakukan & 36 & 45,0 \\
\hline Jumlah & 80 & 100 \\
\hline
\end{tabular}

Berdasarkan table 2 pada indikator tangiable support lebih banyak yang dilakukan yaitu berjumlah 37 orang (46,2\%), indikator belonging support lebih banyak yang dilakukan yaitu berjumlah 36 orang $(45,0 \%)$, indikator self-esteem support lebih banyak yang dilakukan yaitu berjumlah 27 orang $(33,8 \%)$, serta pada indikator appraisal support lebih banyak dilakukan yang berjumlah 36 orang $(45,0 \%)$.

Tabel 3

Distribusi Frekuensi Mekanisme Koping Santri

\begin{tabular}{lcc}
\hline Mekanisme Koping & Frekuensi & Persentase \\
\hline Maladaptif & 35 & 43,8 \\
\hline Adaptif & 45 & 56,2 \\
\hline Jumlah & 80 & 100 \\
\hline Sumber: Data Primer Lembar Kuesioner Penelitian 2020
\end{tabular}

Berdasarkan tabel 3 diatas menunjukkan bahwa mayoritas memiliki mekanisme koping maladaptif dengan jumlah santri 35 orang dan presentasenya sejumlah $43,8 \%$ sedangkan presentase tertinggi yaitu $56,2 \%$ dengan jumlah santri 45 orang dalam hal ini menunjukkan mekanisme koping yang adaptif. 
Tabel 4

Distribusi Frekuensi Indikator Mekanisme Koping Santri

\begin{tabular}{lcc}
\hline $\begin{array}{l}\text { Indikator Mekanisme } \\
\text { Koping }\end{array}$ & Frekuensi & Persentase \\
\hline $\begin{array}{l}\text { Emotional Focused Coping } \\
\text { Tidak Dilakukan }\end{array}$ & 40 & 50,0 \\
\hline Dilakukan & 40 & 50,0 \\
\hline Jumlah & 80 & 100 \\
\hline Problem Focused Coping & & \\
\hline Tidak Dilakukan & 39 & 48,8 \\
\hline Dilakukan & 41 & 51,2 \\
\hline Jumlah & 80 & 100 \\
\hline Sum: Data Pritin
\end{tabular}

Berdasarkan tabel 4 pada indikator emotional focused coping lebih banyak yang dilakukan yaitu berjumlah 40 orang $(50,0 \%)$, dan pada indikator problem focused coping lebih banyak yang dilakukan yaitu 41 orang $(51,2 \%)$.
Tabel 5

Distribusi Frekuensi Tingkat Stress Santri

\begin{tabular}{lcc}
\hline Dukungan Sosial & Frekuensi & Persentase \\
\hline Ringan & 32 & 40,0 \\
\hline Sedang & 44 & 55,0 \\
\hline Berat & 4 & 5,0 \\
\hline Jumlah & 80 & 100 \\
\hline Sumber: Data Primer Lembar Kuesioner Penelitian 2020
\end{tabular}

Berdasarkan tabel 5 menunjukkan bahwa tingkat stress santri yang mengalami tingkat stress sedang dengan jumlah presentase 55,0\% dengan jumlah santri 44 orang, untuk stress dengan kategori ringan dengan presentase $40,0 \%$ dengan jumlah santri 32 orang, presentase terkecil berada pada tingkatas stress kategori berat dengan jumlah santri 4 orang $(5,0 \%)$.

Tabel 6

Hubungan Dukungan Sosial Dengan Tingkat Stress

\begin{tabular}{|c|c|c|c|c|c|c|c|c|c|}
\hline \multirow{3}{*}{ Dukungan Sosial } & \multicolumn{8}{|c|}{ Tingkat Stress } & \multirow[t]{3}{*}{ p-value } \\
\hline & \multicolumn{2}{|c|}{ Ringan } & \multicolumn{2}{|c|}{ Sedang } & \multicolumn{2}{|c|}{ Berat } & \multicolumn{2}{|c|}{ Total } & \\
\hline & $\mathrm{N}$ & $\%$ & $\mathrm{~N}$ & $\%$ & $\mathrm{~N}$ & $\%$ & $\mathrm{~N}$ & $\%$ & \\
\hline Rendah & 12 & 15,0 & 14 & 17,5 & 0 & 0,0 & 26 & 32,5 & \multirow{4}{*}{0,018} \\
\hline Sedang & 0 & 0,0 & 6 & 7,5 & 2 & 2,5 & 8 & 10,0 & \\
\hline Tinggi & 20 & 25,0 & 24 & 30,0 & 2 & 2,5 & 46 & 57,5 & \\
\hline Total & 32 & 40,0 & 44 & 55,0 & 4 & 5,0 & 80 & 100 & \\
\hline
\end{tabular}

Sumber: Data Primer Lembar Kuesioner Penelitian 2020

Berdasarkan Table 6 didapatkan hasil bahwa santri dengan dukungan sosial rendah mengalami tingkat stress ringan sebanyak 12 santri $(15,0 \%)$, santri dengan dukungan sosial sedang tidak ada santri yang mengalami tingkat stress ringan, dukungan sosial tinggi dengan tingkat stress ringan terdapat 20 santri $(25,0 \%)$, santri dengan dukungan sosial rendah yang mengalami tingkat stress sedang terdapat 14 santri $(17,5 \%)$, santri dengan dukungan sosial sedang yang mengalami tingkat stress sedang terdapat 6 santri $(7,5 \%)$, dukungan sosial tinggi dengan tingkat stress sedang terdapat 24 santri $(30,0 \%)$, santri dengan dukungan sosial rendah yang mengalami tingkat stress berat tidak ada, santri dengan dukungan sosial sedang yang mengalami tingkat stress berat terdapat 2 santri $(2,5 \%)$, dukungan sosial tinggi dengan tingkat stress berat 2 santri dengan presentse $2,5 \%$.

Pada analisis diatas juga dapat diketahui bahwa hubungan dukungan sosial dengan tingkat stress santri di Pondok Pesantren Nurul Jaidid Paiton Probolinggo sebelum dan sesudah pengambilan sampel menunjukkan nilai $p$-value yaitu 0,018 pada 80 sampel. Nilai tersebut lebih kecil dari $\leq 0,05$ dengan demikian Ha diterima, yang artinya adalah terdapat hubungan antara dukungan sosial dengan tingkat stress santri di Pondok Pesantren Nurul Jaidid Paiton Probolinggo. 
Tabel 7

Hubungan Mekanisme Koping Dengan Tingkat Stress

\begin{tabular}{|c|c|c|c|c|c|c|c|c|c|}
\hline \multirow{3}{*}{ Dukungan Sosial } & \multicolumn{8}{|c|}{ Tingkat Stress } & \multirow[t]{3}{*}{ p-value } \\
\hline & \multicolumn{2}{|c|}{ Ringan } & \multicolumn{2}{|c|}{ Sedang } & \multicolumn{2}{|c|}{ Berat } & \multicolumn{2}{|c|}{ Total } & \\
\hline & $\mathrm{N}$ & $\%$ & $\mathrm{~N}$ & $\%$ & $\mathrm{~N}$ & $\%$ & $\mathrm{~N}$ & $\%$ & \\
\hline Maladaptif & 20 & 25,0 & 14 & 17,5 & 1 & 1,2 & 35 & 43,8 & \\
\hline Adaptif & 12 & 15,0 & 30 & 37,5 & 3 & 3,8 & 45 & 56,2 & 0,021 \\
\hline Total & 32 & 40,0 & 44 & 55,0 & 4 & 5,0 & 80 & 100 & \\
\hline
\end{tabular}

Sumber: Data Primer Lembar Kuesioner Penelitian 2020

Berdasarkan Tabel 7 didapatkan hasil bahwa santri dengan mekanisme koping maladaptif mengalami tingkat stress ringan sebanyak 20 santri $(25,0 \%)$, santri dengan mekanisme koping adaptif dengan tingkat stress ringan 12 santri $(15,0 \%)$, mekanisme koping maladaptif dengan tingkat stress sedang 14 santri $(17,5 \%)$, mekanisme koping adaptif dengan tingkat stress sedang 30 santri (37,5\%), mekanisme koping maladaptif dengan tingkat stress berat 1 santri $(1,2 \%)$, mekanisme koping adaptif dengan tingkat stress berat 3 santri dengan presentase $3,8 \%$.

Pada analisis diatas juga dapat diketahui bahwa hubungan mekanisme koping dengan tingkat stress santri di Pondok Pesantren Nurul Jaidid Paiton Probolinggo sebelum dan sesudah pengambilan sampel menunjukkan nilai $\mathrm{p}$-value yaitu 0,021 pada 80 sampel. Nilai tersebut lebih kecil dari $\leq 0,05$ dengan demikian Ha diterima, yang artinya adalah terdapat hubungan antara mekanisme koping dengan tingkat stress santri di Pondok Pesantren Nurul Jaidid Paiton Probolinggo.

\section{PEMBAHASAN}

Hasil penelitian ini menunjukkan bahwa dukungan sosial tinggi sejumlah 46 santri $(57,5 \%)$ di Pondok Pesantren Nurul Jadid. Hal ini menunjukkan santri di Pondok Pesantren Nurul Jadid mendapatkan dukungan sosial dengan kategori tinggi, yang disebabkan karena santri di pesantren mempunyai banyak dukungan dari orang sekitar untuk menjalan banyaknya kegiatan walaupun kegiatan di pesantren padat. Dengan begitu santri yang menerima dukungan sosial yang tinggi bisa menjalankan kegiatan dengan semangat. Individu yang memiliki dukungan sosial yang tinggi memiliki seseorang yang memberikan solusi atas permasalahannya, meyakinkan individu bahwa permasalahan dapat diatasi, dan mengingatkan individu untuk melihat sisi positif dari kehidupannya. Sedangkan individu yang memiliki dukungan sosial yang rendah cenderung kurang mendapatkan keuntungan, sehingga mengalami dampak negatif dari stres yang dialaminya (Sarafino, 2011). Hasil penelitian tersebut sejalan dengan hasil penelitian Syahria yang menunjukkan bahwa dukungan sosial yang diterima oleh subjek adalah tinggi, artinnya subjek dalam penelitian ini mempersepsikan bahwa dirinya menerima dukungan sosial yang ditujukan kepadanya, baik dalam bentuk emosional, dukungan penghargaan, dukungan instrumental dan dukungan informasional serta dukungan dari kelompok sosial (Syahria \& Rohmatun, 2018).

Dukungan sosial dibagi menjadi beberapa aspek yaitu appraisal support, tangible support, self-esteem support, belonging support. Dari hasil penelitian pada hasil penelitian ini didapatkan nilai aspek yang paling banyak dilakukan adalah dukungan sosial tangible support sebanyak 37 santri dengan presentase 46,2 \%. Dukungan instrumental atau tangible support ialah dukungan nyata yang diberikan dalam bentuk wujud barang, seperti bantuan keuangan, barang, atau layananan (Kaakinen, 2015). Tangible support menjadi salah satu aspek keterampilan dan mengatasi masalah (Terry, 2012). 
Khususnya santri dengan paling banyak dukungan instrumental atau tangible support didapatkan berupa dukungan nyata dari teman sekamar maupun kakak kelas dan adik kelasnya serta pengurus di wilayahnya untuk bisa menyelesaikan suatu masalah yang sedang dihadapinya. Hasil penelitian ini sesuai dengan penelitian Inge yang menunjukkan bahwa kenaikan atau penurunan dukungan instrumental akan mengakibatkan penurunan atau kenaikan pada stress. Sehingga apabila dukungan instrumental naik satu tingkatan maka stress diprediksi akan mengalami penurunan dan sebaliknya apabila dukungan instrumental mengalami penurunan akan mengalami kenaikan, yang artinya pemberian dukungan instrumental ini jika diberikan akan membantu individu dalam kelaksanakan kegiatannya sehingga mampu mengurangi perasaan ketidakmampuan individu dalam melakukan pekerjaannya (Inge \& Hermian, 2012). Dalam hal ini telah dijelaskan oleh Schwarzer yang menyatakan bahwa dukungan sosial mengacu pada fungsi dan kualitas hubungan sosial, seperti persepsi ketersediaan bantuan atau dukungan yang benar-benar diterima (Schwarzer, 2003).

Hasil penelitian ini menunjukkan bahwa mayoritas santri Pondok Pesantren Nurul Jadid memiliki mekanisme koping yang adaptif sejumlah 45 santri dengan presentase $56,2 \%$, yang artinya santri di Pondok Pesantren Nurul Jadid berusaha menyelesaikan masalahnya dengan baik serta berpegang pada pendiriannya terhadap hal yang dikehendaki walaupun kegiatan di pesantren begitu padat. Sesuai dengan penelitian yang dilakukan oleh Mesarini \& Astuti "Stress dan Mekanisme Koping Terhadap Gangguan Siklus Menstruasi pada Remaja Putri" menunjukkan responden menggunakan mekanisme koping yang adaptif dalam memecahkan masalahnya. Hal tersebut dipengaruhi oleh keyakinan pada saat menghadapi masalahnya serta memecahkan masalahnya tersebut dengan cara mencari informasi, mengidentifikasi masalah dengan harapan menghasilkan alternatif tindakan, kemudian mempertimbangkan kembali alternatif tindakan tersebut dengan hasil yang ingin di capai (Mesarini \& Astuti, 2013).

Berdasarkan hasil penelitian ini koping paling banyak dilakukan diantaranya problem focused coping sebanyak 41 santri dengan presentase $51,2 \%$, karena stress dalam menjalankan kegiatan yang padat dan tuntutan yang harus di patuhi. Dengan seperti itu santri sering kali konsultasi dengan pengurus ataupun kakak kelas mengenai kegiatan yang padat dan tuntutan tersebut agar masalah dalam kegiatan ataupun tuntutan bisa teratasi secara tuntan dan hasilnya akan mengurangi stressor yang ada. Penelitian ini sesuai dengan penelitian Andria yang menunjukkan bahwa banyak mahasiswa yang sedang menghadapi tugas akhir yaitu skripsi, dengan memilih menggunakan metode mekanisme koping yang berfokus pada masalah untuk digunakan mengubah situasi, keadaan atau pokok permasalahan yang ada dengan cara sering konsultasi dengan dosen pembimbing tentang penyusunan skripsi (Andria \& Wilda, 2019). Problem focused coping meliputi pikiran, tingakan dan strategi yang bertujuan menghilangkan situasi yang tidak menyenangkan dan dampaknya (Lazarus \& Folkman, 1984). Setiap orang berbeda-beda bagaimana cara mereka mengatasi suatu masalah yang dialaminya. Cara orang menangani stress disebut koping yang artinya jika, seseorang yang memiliki mekanisme koping yang adaptif, maka ia akan berusaha menyelesaikan masalahnya, sedangkan seseorang yang memiliki mekanisme koping yang maladaptif biasanya tidak dapat menyelesaikan masalahnya secara tuntas (Ihdaniyati \& Arifah, 2005).

Hasil penelitian ini menunjukkan bahwa mayoritas santri Pondok Pesantren Nurul Jadid mengalami Stress sedang dengan jumlah 44 santri $(55,0 \%)$, yang berarti santri di Pondok Pesantren Nurul Jadid bisa meminimalisir tingkat stressnya, dibuktikan 
dengan adanya dukungan sosial yang tinggi serta mekanisme koping yang adaptif.

Pada kegiatan santri di pondok pesantren yang sangat banyak sekali sehingga santri akan merasa adanya tuntutan atau beban, sulit tidur, tidak bisa konsentrasi yang merupakan tanda dan gejala dari stress. Walaupun santri memiliki jadwal kegiatan dan tugas yang padat di Pondok Pesantren Nurul Jadid, hal tersebut tidak membuat santri dalam kondisi tertekan. Pada hasil penelitian Ayu menunjukkan bahwa responden lebih dominan yang mengalami stress sedang sebanyak 38 orang $(52,8 \%)$ yang disebabkan oleh kegiatan pembelajaran pondok yang terlalu padat, peraturan yang ketat, aktivitas yang banyak, hafalan yang harus dikuasai, serta banyak beban tuntutan yang harus dicapai (Ayu, 2017). Walaupun kegiatan serta tuntutan di pesantren begitu banyak masih ada dukungan dari teman maupun pengurus bagi santri untuk terus menjalankan kegiatan dan peraturan yang sudah ada di pesantren karena, dengan dukungan sosial yang tinggi santri bisa menurunkan tingkat stressnya. Maka stress yang awalnya tidak bisa di atasi menjadi teratasi sebagian oleh dukungan dari semua pihak untuk santri. Dengan dukungan sosial yang nyata dari semua pihak hasil bisa juga membuat santri lebih berantusias untuk melaksanakan kegiatan yang padat. Karena salah satu cara untuk mengatasi atau menghadapi masalah atau mengalami stress bisa dengan mendapat atau menerima dukungan sosial dari semua pihak yang mengenalinya. Dan penelitian ini sesuai dengan penelitian Akhmad menunjukkan ada hubungan yang signifikan antara dukungan sosial dengan tingkat stress. Penelitian ini menunjukkan bahwa apabila dukungan sosial semakin besar maka semakin rendah tingkat stress dan demikian sebaliknya (Akhmad, 2019).

Dalam hal ini bahwa santri menggunakan koping adaptif untuk mengatasi stressnya karena, walaupun ada kegiatan atau tuntutan yang tidak disenangi atau diminati santri. Santri tetap mencari solusi dengan cara yang baik agar bisa menerima kegiatan atau tuntutan dengan baik karena dengan cara santri menggunakan mekanisme koping adaptif maka tingkat stress semakin ringan begitupun sebaliknya. Dari situ santri mudah mengalami stress apabila tidak menggunakan coping yang adatif karena, dengan koping yang adaptif bisa membuat santri yang mengalami stress bisa menangani stress dengan baik. Dan apabila santri menggunakna mekanisme koping yang maladaptif maka stressny tak kunjung selesai. Karena koping yang maladaptif yang digunakan santri di Pondok Pesantren seperti halnya merokok, melanggar peraturan pesantren, kabur, menggunakan alat elektronik seperti mengoperasikan handphone tanpa seizin pengasuh di Pesantren.

Dan penelitian ini sesuai dengna penelitian Ima yang menunjukkan terdapat hubungan mekanisme koping dengan tingkat stress pada pasien kanker di Yayasan Kanker Indonesia Cabang Jawa Timur. Hal ini dapat diartikan sebagian besar mempunyai mekanisme koping maladaptif dan hampir setengah mengalami stress dengan tingkat stress berat. Pasien yang mengalami mekanisme koping adaptif sebagian besar dengan tingkat stress ringan. Dengan demikian pasien kanker di Yayasan Kanker Indonesia Cabang Jawa Timur mekanisme mempunyai mekanisme koping sesuai dengan tingkat stress yang dialami selama menjalankan masa pengobatan (Ima \& Mulayyinah, 2019). Begitupun juga dengan penelitian Grace didapatkan bahwa terdapat hubungan antara mekanisme koping dengan stress kerja perawat di RSU GMIM Bethesda Tomohon. Hal ini dapat diartikan bahwa sebagian besar responden memiliki mekanisme koping adaptif dan sebagian besar mengalami stress kerja sedang (Grace \& Rina, 2019).

\section{Simpulan}

Terdapat hubungan antara dukungan sosial dengan tingkat stress santri di Pondok Pesantren Nurul Jadid. Artinya semakin tinggi dukungan sosial maka 
semakin mengurang tingat stress yang dialami santri dan semakin rendah dukungan sosial maka semakin meningkat tingkat stress yang dialami santri.

Terdapat hubungan antara mekanisme koping dengan tingkat stress santri di Pondok Pesantren Nurul Jadid. Artinya semakin santri menggunakan mekanisme koping adaptif untuk mengatasi stressnya maka semakin berkurang tingkat stressnya yang dalaminya dan apabila santri menggunakan koping maladaptif untuk mengatasi stressnya maka semaking meningkat tingkat stress yang dialaminya.

\section{DAFTAR PUSTAKA}

[1] A. Linda Yani, A. Retnowuni. (2019). Faktor-faktor yang Mempengaruhi Perilaku Agresif pada Remaja yang Tinggal di Pesantren.

[2] Y. Astuti. (2015). Hubungan Antara Dukungan Sosial Orang Tua Dengan Strategi Coping Berfokus Masalah Siswa SMK Negeri 3 Yogyakarta.

[3] S. Millasari, S. Jannah. (2019). Hubungan Antara Sistem Pembelajaran Dengan Tingkat Stress dan Adaptasi pada Siswa Pesantren Aceh Besar.

[4] I. Hanifah. (2019). Dukungan Sosial Dengan Coping Stress Pada Siswa SMP.

[5] Y. Livia Fitriani, Zulia Putri Perdana. (2020). Hubungan Tingkat Stress Remaja dengan Kemampuan Beradaptasi di Pondok Pesanten Kota Tangerang.

[6] Riskesdas. (2018). Kementrian Kesehatan Badan Penelitian Dan Pengembangan Kesehatan. http://www.depkes.go.id/resources/do wnload/info-terkini/hasil-riskesdas2018.pdf

[7] Sarwono. (2011). Ilmu Kebidanan. Jakarta: PT. Bina Pustaka Sarwono Prairohardjo.

[8] Kuntjoro. (2012). Hubungan Dukungan Sosial dengan Tingkat Sosial Pada Lansia. Surakarta:
Fakultas Ilmu Kesehatan

Muhammadiyah.

[9] Lazarus, Richard S \& Susan Folkman. (1984). Stress, appraisal, and coping. New York. Springer Publishing Company.

[10] Selye, H. (1907). Stress in Health and Disease. America: Butterworth.

[11] Sarafino, E \& Smith, T. (2011). Health Psychology Biopsychosocial Interaction. United State Of Amerika: John Wlley \& Sons.

[12] Syahria, N. J., \& Rohmatun. (2018). Hubungan Antara Dukungan Sosial dengan Resiliensi pada Penyintas Banjir Rob Tambak Lorok Proyeksi, Vol. 13 (1), 1-12.

[13] Kaakinen, J., Coehlo, D., Steele, R., \& Robinson, M. (2015). Family health care nursing: Theory, practice, and research (5th ed). USA: F.A. Davis Company.

[14] Terry, D. J. (2012). Social Supports And Criminal Desistance Among Formerly Incarcerated Youth In The Transition To Adulthood (Order No. 3527490). Available from ProQuest Dissertations \& Theses Global. (1095380368). Retrieved from https://search.proquest.com/docview/1 095380368 ? accountid=17242.

[15] Inge, H. P., \& Hermian L. (2012). Pengaruh Dukungan Emosional, Dukungan Penghargaan, Dukungan Instrumental dan Dukungan Infromatif Terhadap Stress pada Remaja di Yayasan Panti Asuhan Putra Harapan Asrori Malang. Jurnal Ilmiah.

[16] Mesarini, B. A., \& Astuti, V. W. (2013). Stres Dan Mekanisme Koping Terhadap Gangguan Siklus Menstruasi Pada Remaja Putri, 6(1), 31-42.

[17] Rasmun. (2009). Stres, Mekanisme Koping dan Adaptasi. Jakarta: CV Agung Seto.

[18] Andria P., \& Wida U. (2019). Gambaran Mekanisme Coping pada Mahasiswa Program Studi Sarjana Keperawatan Tingkat IV yang Sedang Menghadapi Tugas Akhir di Sekolah 
Tinggi Ilmu Kesehatan X Bandung. Humanitas Vol. 3 No. 2.

[19] Lazarus, Richard S \& Susan Folkman. (1984). Stress, appraisal, and coping. New York. Springer Publishing Company.

[20] Ihdaniyati, A. I., \& Arifah, S. (2005). Hubungan Tingkat Kecemasan Dengan Mekanisme Koping Pada Pasien Gagal Jantung Kongestif Di Rsu Pandan Arang Boyolali, 19-24.

[21] Ayu, S., J. (2017). Hubungan Tingkat Stress Dengan Strategi Koping yang Digunakan pada Santri Remaja di Pondok Pesantren Nurul Alimah Kudus. Prosiding Hefa.

[22] Akhmad, Y., F., P. (2019). Hubungan Dukungan Sosial dengan Tingkat Stress pada Warga Binaan Permasyarakatan Perempuan di Lembaga Pemasyarakatan. Juournal of Holistic Nursing and Health Science. Vol 2.
[23] Rani, D., H., Asri, M., P., \& Dita, F. (2019). Hubungan Antara Dukungan Sosial dengan Tingkat Stress Orang Tua dengan Anak Penderita Autisme. Jurnal Psikologi Universitas Muhammadiyah Lampung Vol. 1 No.2.

[24] Ima N., \& Mulayyinah. (2019). Hubungan Mekanisme Koping Dengan Tingkat Stress pada Pasien Kanker di Yayasan Kanker Indonesia Cabang Jawa Timur. JI-KES: Jurnal Ilmu Kesehatan Vol. 2 No. 2.

[25] Grace, J., M., B H., R., K., \& Rina, K. (2019). Hubungan Mekanisme Koping dengan Stress Kerja Perawat di RSU GMIM Bethesda Tomohon. e-journal Keperawatan (e-Kp) Vol. 7 No. 1.

[26] Sunaryo. (2004). Psikologi untuk keperawatan. Jakarta: EGC. 